\title{
Isolation, characterization and toxicity of native Bacillus thuringiensis isolates from different hosts and habitats in Iran
}

\author{
Akbar Ghassemi-Kahrizeh ${ }^{1}$, Ayda Khoramnezhad ${ }^{2}$, Reza Talaei-Hassanloui ${ }^{2 *}$ \\ ${ }^{1}$ Department of Plant Protection, Mahabad Branch, Islamic Azad University, Mahabad, Iran \\ ${ }^{2}$ Department of Plant Protection, College of Agriculture and Natural Resources, University of Tehran, Karaj, 31587-77871, Iran
}

Vol. 57, No. 3: 212-218, 2017

DOI: 10.1515/jppr-2017-0029

Received: January 19, 2017

Accepted: July 13, 2017

*Corresponding address:

rtalaei@ut.ac.ir

\begin{abstract}
Bacillus thuringiensis is a Gram-positive, aerobic, facultative anaerobic and endosporeforming bacterium. Different strains of this species have the ability to produce parasporal crystalline inclusions which are toxic to larvae of different insect orders and other invertebrates and cause rapid death of the host. To determine the importance of this species in microbial control, we collected native strains and studied their virulence on the diamondback moth, Plutella xylostella. More than 148 samples were collected from Alborz, Guilan and Mazandaran Provinces. Experimental samples, including soil samples from forests, fruit gardens, agricultural fields, diseased and dead larvae, were transferred to a laboratory in sterile plastic containers. For evaluating $B$. thuringiensis isolates virulence, a cabbage leaf dip method with $10^{6} \mathrm{cell} \cdot \mathrm{ml}^{-1}$ concentration of various Bt isolates was applied to diamondback moths. Larval mortality was recorded $72 \mathrm{~h}$ after treatment. Based on bioassay results, all isolates were classified into three high, medium and low virulence groups. Protein level characterization based on the SDS-PAGE gel analysis showed that two isolates from a high virulence group have proteins of high molecular masses of 121 and $109 \mathrm{kDa}$. Results revealed that there is a positive correlation between protein masses and virulence of isolates. In addition, this research introduced nine strains that are highly toxic to P. xylostella and would be valuable as insecticidal agents for controlling lepidopteran pests.
\end{abstract}

Key words: Bacillus thuringiensis, characterization, isolation, Plutella xylostella, SDS-PAGE, virulence

\section{Introduction}

Bacillus thuringiensis is a Gram-positive, aerobic, facultative anaerobic, endospore-forming bacterium and is distinguished from other Bacillus spp. by its ability to produce indigenous crystals during sporulation. Crystal proteins from many $B$. thuringiensis strains are toxic to lepidopteran pests (Zhong et al. 2000). These crystals are predominantly composed of one or more proteins (Cry and Cyt toxins), also called $\delta$-endotoxins (Bravo et al. 2007), which is specific primarily at the level of insect orders, particularly Lepidoptera, Coleoptera and Diptera and cause gut paralysis in some insect orders, resulting in an inability to feed, starvation and death
(Faknath 1999). Cry proteins are parasporal inclusion (Crystal) from B. thuringiensis that exhibit experimentally verifiable toxic effects on a target organism and Cyt proteins are parasporal inclusion from $B$. thuringiensis that exhibit hemolytic (Cytolitic) activity (Bravo et al. 2007). In Lepidoptera specificity is partly due to an alkaline midgut environment that is needed to solubilize the protoxin into active toxin (Broderick et al. 2006). Protoxins are activated by midgut proteases and bind to specific receptors on the intestinal epithelium by forming pores. Toxins then enter gut cells, leading to cell lysis which provides spores access to a more 
favorable environment of hemocoel. Spores germinate, reproduce and cause septicemia and death (Schnepf et al. 1998). Bacillus thuringiensis is ubiquitous in natural environments and is readily isolated from soil, warehouses, the leaf surfaces of broad leaf trees, conifers, grasses and insect habitats (Zhong et al. 2000).

Diamondback moth, Plutella xylostella (L.) (Lepidoptera, Plutellidae), is a serious and important pest of cruciferous plants worldwide (Talekar and Shelton 1993; Sarfraz et al. 2006; Li et al. 2016). Plutella xylostella occurs annually throughout different regions of Iran wherever cruciferous crops are grown and can cause substantial crop losses during outbreak years (Keyhanian et al. 2005). In Indonesia this pest has been reported as a primary factor in limiting the production of cabbage in many areas (Ahmad 1999). In this study, the virulence of $B$. thuringiensis isolates was evaluated on P. xylostella larvae. The method of controlling this pest has been to spray with chemical pesticides, a strategy that also kills natural enemies and can lead to the rapid development of insecticide resistance in pest species. Therefore, any effort to find new microbial pesticides to control this pest, e.g. ones based on the bacterium $B$. thuringiensis, is highly necessary and desirable.

Isolating native $B$. thuringiensis strains from different habitats, evaluating the insecticidal activity of the strains, characterizing the protein level diversity and finally, determining the correlation between protein masses and virulence were the main objectives of this study.

\section{Materials and Methods}

\section{Sample collection}

A total of 148 samples were collected from environmentally diverse sources in Alborz, Guilan and Mazandaran provinces in Iran. Experimental samples, including soil samples from forests, fruit gardens, agricultural fields, beach sands, urban and rural areas, diseased and dead larvae, were transferred to a laboratory in sterile plastic containers. Soil samples were collected at a depth of 5 to $15 \mathrm{~cm}$ under the surface, away from direct sunlight (Ohba and Aizawa 1986b).

\section{Isolation from soil samples}

Bt strains were isolated according to the sodium acetate selective method of Travers et al. (1987). Approximately $1 \mathrm{~g}$ of soil samples were suspended in $10 \mathrm{ml}$ nutrient broth medium containing $0.25 \mathrm{M}$ and $0.35 \mathrm{M}$ sodium acetate and left for microbial growth at $37^{\circ} \mathrm{C}$ for $4 \mathrm{~h}$. Every $10 \mathrm{~min}$ the containers were shaken well. Heat treatment was then applied for $7 \mathrm{~min}$ at $80^{\circ} \mathrm{C}$ to kill vegetative cells. Using this method, the germination of $B$. thuringiensis spores was inhibited by sodium acetate, thus the germinated spores and other non-spore forming bacteria were eliminated by heat treatment. Next, samples were plated on nutrient agar, incubated at $30^{\circ} \mathrm{C}$ for 4 days and then examined for colony morphology and the presence of parasporal crystals by phase contrast microscopy. All crystal forming colonies were sub-cultured and maintained for further investigation and stored in sterile liquid nutrient broth containing $50 \%$ glycerol at $-20^{\circ} \mathrm{C}$.

\section{Isolation from dead larvae}

Insect cadaver samples were surface sterilized with $0.2 \%$ sodium hypochlorite solution, $70 \%$ ethanol and sterile distilled water. The dissected body contents were placed on nutrient agar. The plates were incubated at $30^{\circ} \mathrm{C}$ for 4 days, and processed as mentioned in the previous section.

\section{Insect toxicity assay}

Mortality data were generated by a cabbage leaf dip bioassay on diamondback moth second instar larvae. An experimental population of $P$. xylostella was established from cabbage farms in Alborz Province. Cabbage leaf disks (50 $\mathrm{mm}$ diameter) were dipped for $10 \mathrm{sec}$ in a $10^{6}$ cell $\cdot \mathrm{ml}^{-1}$ concentration of various $\mathrm{Bt}$ isolates, allowed to air dry and inoculated with 20 larvae per leaf. Mortality was determined after $72 \mathrm{~h}$ but after $24 \mathrm{~h}$ of feeding on contaminated leaves, the treated cabbage disks were replaced with clean ones. Sterile distilled water was used for negative control. Larvae that failed to respond to gentle prodding were considered as dead. Bioassay was carried out on 68 native $\mathrm{Bt}$ isolates and Biolep commercial Bt formulation from Fanavary Zisti Tabiatgara company (Karaj, Iran) in three replicates. Also three reference strains, Bt subsp. kurstaki, Bt subsp. israelensis and Bt subsp. tenebrionis, which were kindly provided by dr. Zihni Demirbag from Karadeniz Technical University (Trabzon, Turkey) were used in this study. According to bioassay results, all isolates were classified into three, high, medium and low, virulence groups.

\section{Growth curve analysis}

Bacterial growth curves were traced for six $\mathrm{Bt}$ isolates. Two isolates from each group of virulence were selected. The designated isolates were inoculated in nutrient broth medium. The growth curve, based on absorbance at $540 \mathrm{~nm}$ at an interval of 24 to $120 \mathrm{~h}$, was generated. During this period, the cells were observed by phase contrast microscopy to identify the sporulation phase. 


\section{Crystal morphology}

Parasporal inclusions were examined before cell lysis by phase contrast microscopy at $1,000 \times$ magnification. Smears of bacterial strains were stained with coomassie brilliant blue solution and observed by phase contrast microscopy with oil emersion. From the three virulence groups, 18 isolates were chosen and inoculated in nutrient broth medium and left for $120 \mathrm{~h}$ to sporulate at $200 \mathrm{rpm}$. When sporulation was completed and crystals and spores were released (as checked by phase contrast microscopy), the colony material was removed from the medium by centrifugation at $6,000 \times \mathrm{g}$ for $15 \mathrm{~min}$, and transferred to sterile microtubes containing $1 \mathrm{ml} 0.5 \mathrm{M} \mathrm{NaCl}$. Re-suspended samples were centrifuged at $17,000 \times \mathrm{g}$ for $12 \mathrm{~min}$ at $4^{\circ} \mathrm{C}$. The discarded supernatant and pellets were re-suspended in $1 \mathrm{ml}$ $0.5 \mathrm{M} \mathrm{NaCl}$. The suspension was centrifuged again as above. The washing procedure was performed twice. The final pellet containing crystals was collected for microscopic observation.

\section{Protein extraction}

From each group of virulence, six Bt isolates and three standard Bt isolates were designated for protein extraction by using the Lowry method (Lowry 1951). After complete autolysis, $1.5 \mathrm{ml}$ of distilled water containing lysed cells were centrifuged at 10,000 rpm for $15 \mathrm{~min}$ at $4^{\circ} \mathrm{C}$. The supernatant was discarded and the pellet was re-suspended in $2 \mathrm{ml}$ of sterile distilled water. The protein quantification was determined by taking an absorbance reading at $630 \mathrm{~nm}$.

\section{Protein electrophoresis}

The protein contents of $21 \mathrm{Bt}$ strains were determined by sodium dodecyl sulfate polyacrylamide gel electrophoresis analysis, as described by Leamlli (1970), using $5 \%$ and $12.5 \%$ acrylamide resolving and separating gels.

\section{Results}

\section{Isolation and morphological characteristics}

Soil samples were the most abundant source of $B$. thuringiensis. Of the 148 analyzed samples, 155 native strains showing typical colonies of the Bacillus genus were found. All isolates were rod shaped indicating their vegetative stage. Based on the capacity of producing parasporal crystal inclusions, Bt isolates were detected. Phase contrast microscopic observation showed both the endospores and parasporal bodies clearly. Most cells were lysed and released the spore and crystals after $120 \mathrm{~h}$. On the basis of microscopic observation, parasporal crystals produced by $B$. thuringiensis isolates, were classified into four morphological groups; bipyramid crystals were mainly in high virulent groups, cube and polyhedron (triangular) crystals were identified in medium virulent groups and round crystals were the most abundant in low virulent groups. Crystal morphology of Bt can give information about target insect spectra (Maeda et al. 2000). Therefore, in order to determine the crystal pathogenicity and virulence, the crystal morphology by phase contrast microscopy should be examined.

\section{Insect toxicity assay}

The bioassay results indicated that nine $\mathrm{Bt}$ isolates were highly toxic against second instar larvae of $P$. $x y$ lostella. The percentages of mortality of Bt isolates in the high virulent groups are shown in Table 1. Among nine isolates of Bt subjected to the high virulent groups, only three isolates of Bt-IE, Bt-IP and Bt-U3a induced mortality above $95 \%$ against second instar larvae of P. xylostella. The Bt-IE and Bt-IP isolates produced $100 \%$ mortality. The percentages of mortality were: 100, 100, 78.4, 97.4, 84.9, 88.9, 77.8, 84.5 and 91.2 with isolates of Bt-IP, Bt-IE, Bt-AR4, Bt-U3a, Bt-AP, Bt-MCh, Bt-MWa, Bt-Sarv1 and Bt-DC, respectively. Bioassay results showed that the commercial and reference isolate (biolep) induced $100 \%$ mortality against second instar larvae of $P$. xylostella.

\section{Bacterial growth curve}

The bacterial growth curve was plotted for six Bt isolates at an interval of 24 to $120 \mathrm{~h}$ to determine their life cycles. During the period of 24, 48, 72, 96 and $120 \mathrm{~h}$, the bacterial cells were observed under a phase contrast microscope to identify the sporulation phase. Based on the results, two isolates of the high virulent groups, Bt-IP and Bt-IE were found to sporulate at $72 \mathrm{~h}$ after inoculation (Fig. 1). Bt-Bua isolate from the medium virulent group sporulated at $72 \mathrm{~h}$ while Bt-DP isolate from the same group sporulated at $68 \mathrm{~h}$ (Fig. 2). Two isolates of the low virulent groups, Bt$\mathrm{BaR}$ and Bt-MW, sporulated 64 and $92 \mathrm{~h}$ after inoculation, respectively (Fig. 3).

\section{Protein extraction}

Quantitative comparison of whole cellular proteins $\left(\mathrm{mg} \cdot \mathrm{ml}^{-1}\right.$ ) of Bt isolates using spectrophotometry showed that the amounts of proteins differed and ranged from 3.39 to $6.01 \mathrm{mg} \cdot \mathrm{ml}^{-1}$ in high virulent groups, from 0.49 to $4.33 \mathrm{mg} \cdot \mathrm{ml}^{-1}$ in medium virulent groups and from 1.84 to $3.78 \mathrm{mg} \cdot \mathrm{ml}^{-1}$ in low virulent groups. 
Table 1. The percentages of mortality of diamondback moth (Plutella xylostella) second instar larvae caused by Bacillus thuringiensis isolates in the high virulent group

\begin{tabular}{cccc}
\hline Isolate & Sample source & Crystal morphology & $\%$ Mortality \pm SE \\
\hline Bt-IP & Plodia interpunctella larvae & bipyramid & $100 \pm 00.0$ \\
Bt-IE & Ectomyelois ceratonia larvae & bipyramid & $100 \pm 00.0$ \\
Bt-AR4 & agricultural field (rice) & bipyramid & $78.4 \pm 04.4$ \\
Bt-U3a & forest & bipyramid & $97.4 \pm 07.5$ \\
Bt-AP & agricultural field (pepper) & bipyramid & $84.9 \pm 12.5$ \\
Bt-MCh & fruit garden (cherry) & bipyramid & $88.9 \pm 02.2$ \\
Bt-MWa & agricultural field (wheat) & bipyramid & $77.8 \pm 08.9$ \\
Bt-Sarv1 & forest & bipyramid & $84.5 \pm 03.8$ \\
Bt-DC & agricultural field (cabbage) & bipyramid & $91.2 \pm 04.4$ \\
Bt-biolep & formulation Bt subsp. kurstaki & bipyramid & $100 \pm 00.0$ \\
\hline
\end{tabular}
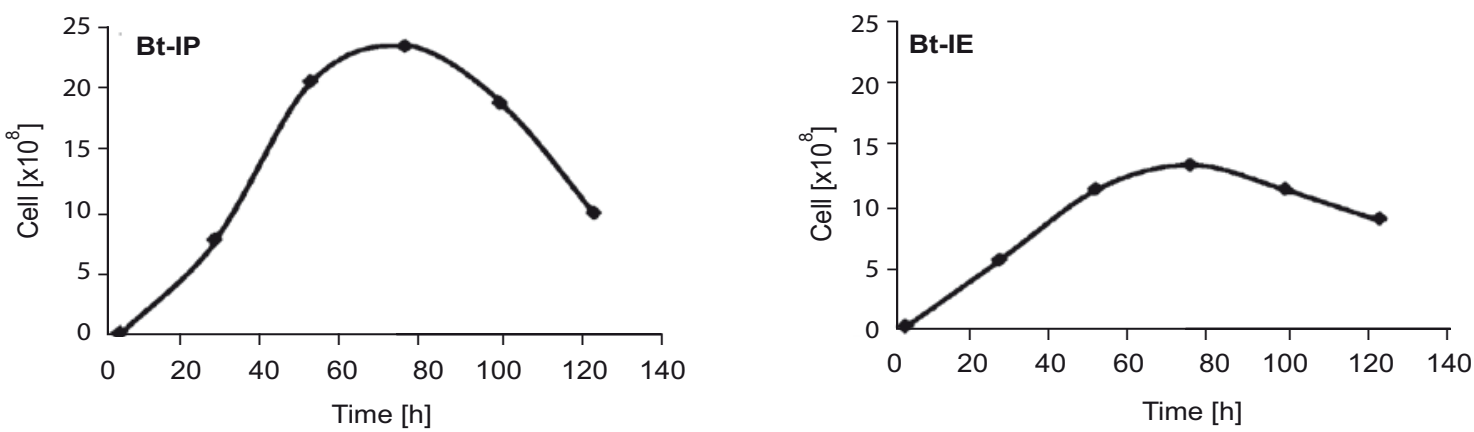

Fig. 1. Growth curves of two Bacillus thuringiensis isolates from the high virulent group: Bt-IP and Bt-IE
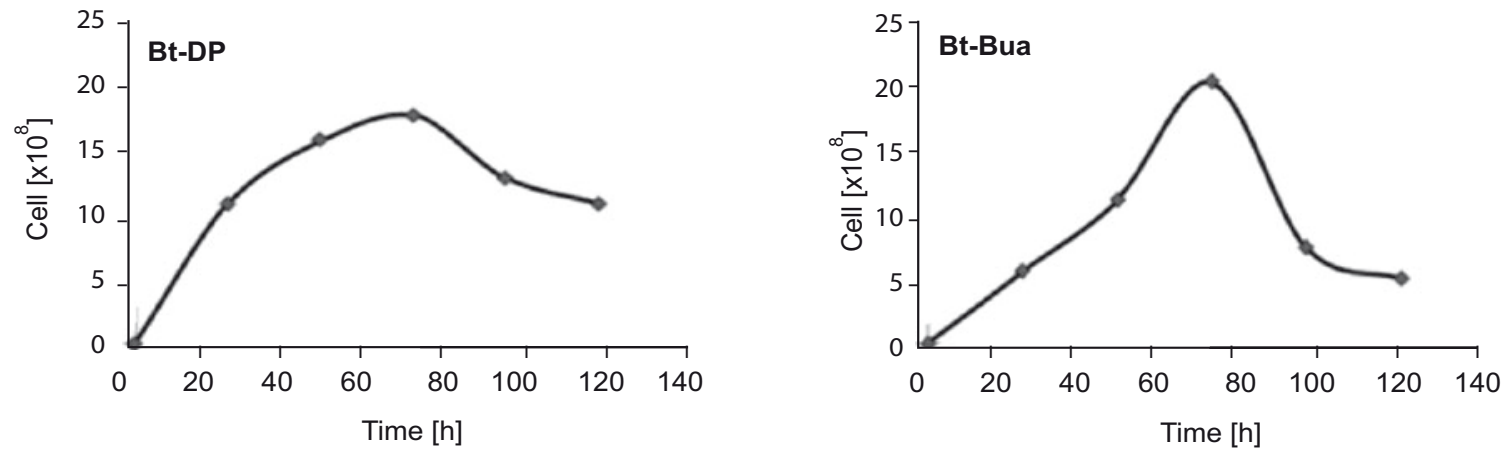

Fig. 2. Growth curves of two Bacillus thuringiensis isolates from the medium virulent group: Bt-DP and Bt-Bua
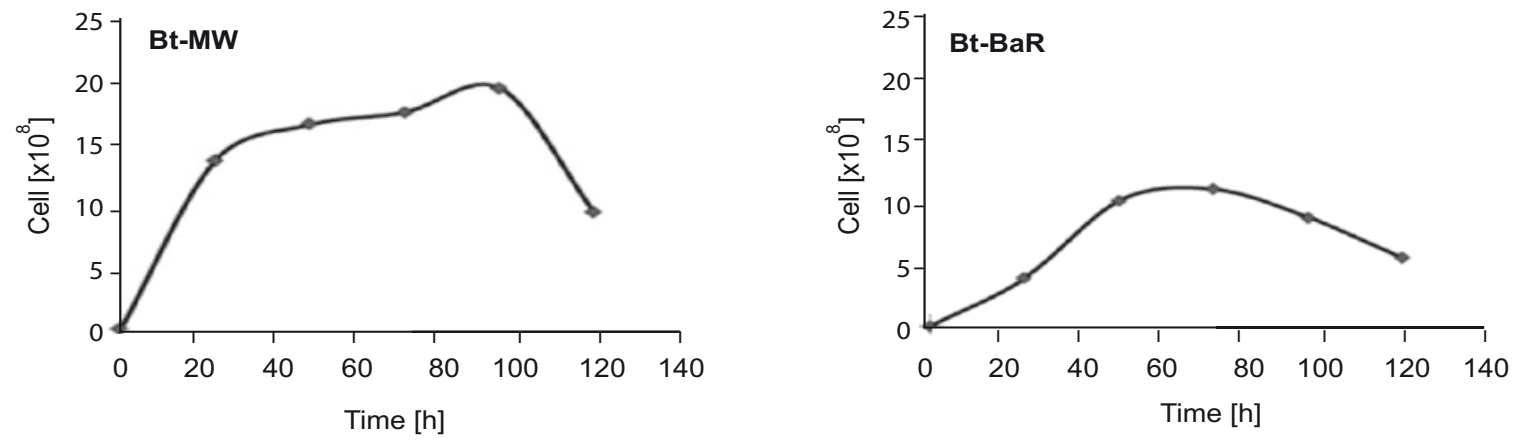

Fig. 3. Growth curves of two Bacillus thuringiensis isolates from the low virulent group: Bt-MW and Bt-BaR 


\section{Protein electrophoresis}

The whole cellular proteins of $21 \mathrm{~B}$. thuringiensis strains as well as three reference strains of this species, B. thuringiensis subsp. israelensis, B. thuringiensis subsp. kurstaki and B. thuringiensis subsp. tenebrionis, were analyzed by SDS-PAGE (Sodium Dodecyl Sulfate-Polyacrylamide Gel Electrophoresis). A great diversity of protein patterns, including both the number and size of protein bands, was found among 21 tested Bt isolates. All the isolates show distinct and clear bands so the existence of Cry proteins can be confirmed (Fig. 4). On the basis of molecular weight,
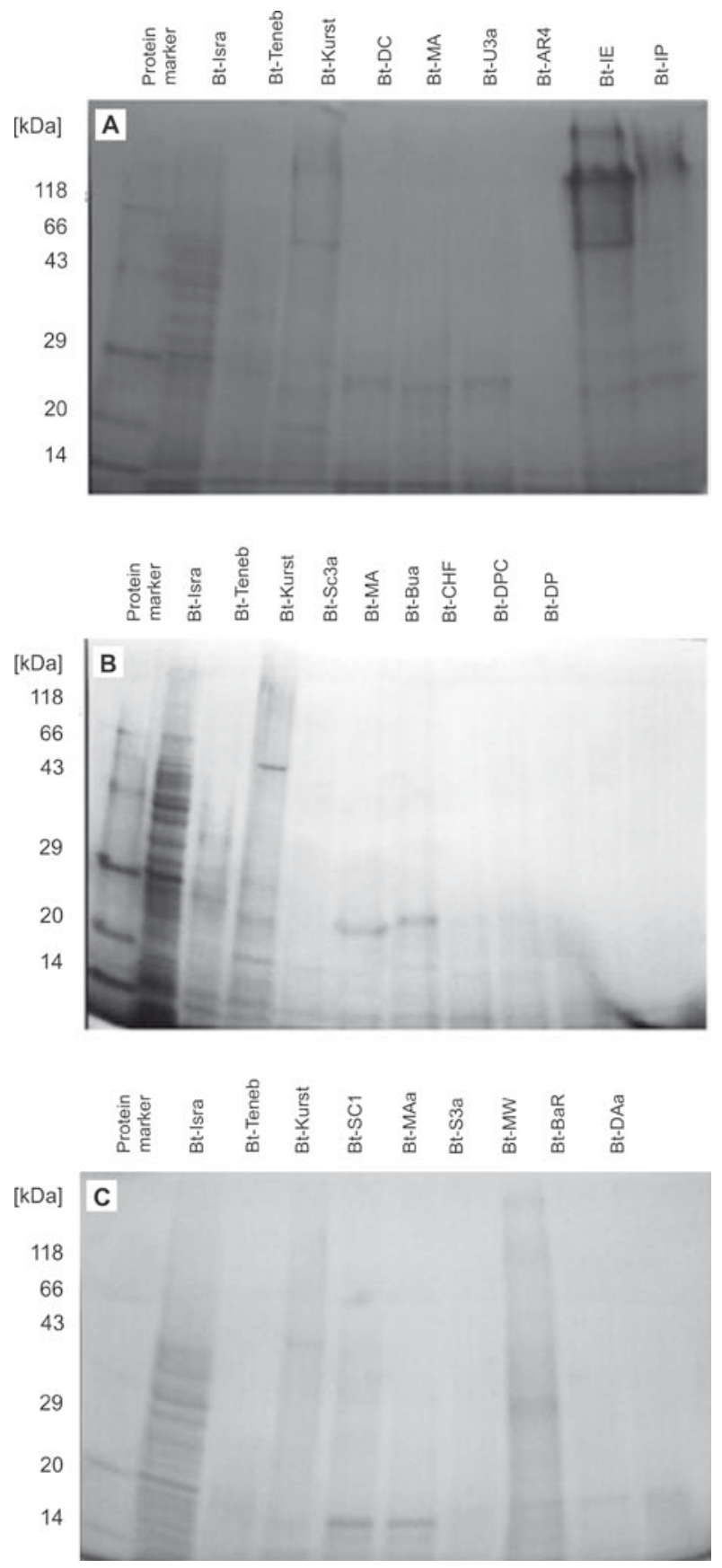

Fig. 4. Protein profiles of whole cellular proteins of Bacillus thuringiensis strains: Bt-Isra, Bt-Teneb and Bt-Kurst are the reference strains. A - high, B - medium, C - low virulent group the protein profiles of Bt strains were in the range of $134.8 \mathrm{kDa}$ to $12.3 \mathrm{kDa}$. The high virulent group exhibited the most protein bands from a maximum molecular mass of $134.8 \mathrm{kDa}$ to minimum of $12.1 \mathrm{kDa}$. Moreover, SDS-PAGE of the high virulent group of isolates showed a protein composition resembling that of the lepidopteran toxic $\mathrm{Bt}$ consisting of major polypeptides in the range of 130 to $140 \mathrm{kDa}$. In the medium virulent group the number and size of protein bands differed from $24 \mathrm{kDa}$ to $16.1 \mathrm{kDa}$ and in the low virulent group the mass of proteins ranged from $112.2 \mathrm{kDa}$ to $12.1 \mathrm{kDa}$.

\section{Discussion}

In the present study, native strains of $B$. thuringiensis were isolated from soil samples and insect cadavers. A total of $155 \mathrm{~B}$. thuringiensis isolates were confirmed according to Travers et al. (1987), bacterial shape, gram staining, the catalase test and the presence of spores and crystals. All isolates were rod shaped, Gram-positive, catalase positive and endospores and parasporal bodies were clearly observed inside all bacterium during the sporulation phase. The autolysis phase of bacterial cells occurred 68 to $92 \mathrm{~h}$ after inoculation. This shows a similar sporulation time as Renganathan et al. (2011) and the standard Bt strain which is approximately $92 \mathrm{~h}$ (Bulla et al. 1980). The bioassay results revealed that Bt isolates differed in their insecticidal activity against second instar larvae of P. xylostella. The slight difference of toxicity between strains could be due to the spore crystal ratio, different Cry protein content and activity of trypsin (Oppert et al. 2010). The results of the bioassay of 68 isolates led to the introduction of nine isolates that are highly toxic to P. xylostella larvae causing $100 \%$ to $78.3 \%$ mortality and will be valuable as insecticidal agents. These nine strains originated from different sources: insects, agricultural fields, forests and fruit gardens (Table 1).

In this study the differences among Bt isolates determined according to parasporal crystals morphology, spectrophotometry to reveal protein concentration and SDS-PAGE to specify the presence of proteins in spores and crystal mixtures. Bt strains produce parasporal inclusions with different morphologies, sizes and numbers. On the basis of microscopic observations, parasporal crystals were classified into four morphological classes: bipyramid, cubical, polyhedron (triangular) and round crystals. Diverse crystal inclusion morphologies were identified among 376 isolates that Vidal-Quist et al. (2009) studied: bipyramid, round, adhered to spore, small and irregular. It has been shown that some distinct morphologies are apparent; bipyramidal crystals related to Cryl proteins, cuboidal inclusions related to Cry 2 proteins, flat and square 
crystals related to Cry3 proteins. Crystal morphology of Bt can provide valuable information on target insect spectra (Hernstand et al. 1986; Ohba and Aizawai 1986a; Asokan et al. 2013). In this study, bipyramid crystals were observed in isolates with the highest toxicity against second instar larvae of P. xylostella. Quantitative protein analysis indicated that Bt isolates differed in their amount of protein and it is noteworthy that there is a correlation between the amount of protein and the insecticidal activity of isolates. These results are similar to Schnepf et al. (1998) who reported that the entomopathogenic properties of Bt strains are attributed largely to the parasporal crystals, which contain one or more insecticidal protoxins produced during bacterial sporulation. Also, Maeda et al. (2000) believed that there is a relationship between toxic activity and the crystal shape of Bt strains. The total protein extracts of the 21 isolated strains revealed protein bands ranging from $134.8 \mathrm{kDa}$ to $12.3 \mathrm{kDa}$, suggesting variable biological activity and specificity for different insect pests. The $130-140 \mathrm{kDa}$ proteins are the usual bands produced by lepidopteran-active strains of Bt producing bipyramidal crystals comprised of Cryl proteins (van Frankenhuyzen 2009). Bt-IP and Bt-IE isolates displayed similar results. Hongyu et al. (2000b) found five protein profiles through characterization of Bt strains from Chinese stored products. QuezadaMoraga et al. (2004) reported 65 different protein profiles among 109 native Bt strains. Hernandez-Fernandez et al. (2010) introduced 18 different profiles based on the presence of four crystal forms. There is a probable relationship between molecular weight and Cry proteins (Aronson et al. 1986; Crickmore et al. 2010). Federici et al. (2006) reported that the Bt strains are recognized as types of crystal proteins. Cry proteins are generally either $60-80 \mathrm{kDa}$ or $130-150 \mathrm{kDa}$. Cyt proteins are approximately $28 \mathrm{kDa}$. The most common pattern of protein profiles in Swamy et al. (2013) isolates was composed of proteins with molecular weights between $60-135 \mathrm{kDa}$. The Lip strain that El Khoury et al. (2014) studied, produced bipyramidal and cubic crystalline inclusions suggesting the presence of Cry1A (135 kDa) and Cry2A (70 kDa) proteins. SDS-PAGE separation of crystal proteins also showed two significant bands with weights of 135 and $65 \mathrm{kDa}$. Morphology and genetic composition of $\mathrm{Bt}$ is highly variable among different types of soils and places. Bt composition seems to be influenced by several factors including soil humidity, organic matter, temperature, structure and $\mathrm{pH}$, micro/macro-nutrients, richness and local insect distribution (Uribe 2004).

Further investigation is needed to characterize the $B$. thuringiensis isolates from other habitats such as stored products. Hongyu et al. (2000a) and Bernhard et al. (1997) reported that Bt is more abundant in the environments of stored products than in soil, dust and leaf surfaces, so that new isolates of Bt could be identified and used as an effective insect pathogen against pests of different orders of insects. Observed SDS-PAGE profiles with corresponding gene profiles via PCR should be compared.

\section{Acknowledgements}

Financial support by Mahabad Branch, Islamic Azad University of this project No. 11665920902001 and technical help by the Biological Control Lab., College of Agriculture and Natural Resources, University of Tehran are acknowledged.

\section{References}

Ahmad I. 1999. Dosage mortality studies with Bacillus thuringiensis and Neem extract on diamondback moth, Plutella xylostella (Lep.: Plutellidae). Indonesian Journal of Plant Protection 5 (2): 67-71.

Aronson A., Beckman W., Dunn P. 1986. Bacillus thuringiensis and related insects pathogens. Microbiological Reviews 50 (1): $1-24$.

Asokan R., Sway H.M., Birah A., Thimmegowda G.G. 2013. Bacillus thuringiensis isolates from great Nicobar Islands. Current Microbiology 66 (6): 621-626. DOI: https://doi. org/10.1007/s00284-013-0323-8

Bernhard K., Jarrett P., Meadows M., Butt J., Pauli S. 1997. Natural isolates of Bacillus thuringiensis: Worldwide distribution, characterization, and activity against insect pests. Journal of Invertebrate Pathology 70: 59-68.

Bravo A., Gill S.S., Soberon M. 2007. Mode of action of Bacillus thuringiensis Cry and Cyt toxins and their potential for insect control. Toxicon 49 (4): 423-435. DOI: https://doi. org/10.1016/j.toxicon.2006.11.022

Broderick N.A., Raffa K.F., Handelsman J. 2006. Midgut bacteria required for Bacillus thuringiensis insecticidal activity. Proceedings of the National Academy of Sciences of the USA 103 (41): 15196-15199. DOI: https://doi.org/10.1073/ pnas.0604865103

Bulla L.A., Bechtel D.B., Kramer K.J., Shethna Y.I., Aronson A.I., Fitz-James P.C. 1980. Ultrastructure, physiology and biochemistry of Bacillus thuringiensis. Critical Reviews in Microbiology 8 (2): 147-204. DOI: 10.3109/ 10408418009081124

Crickmore N., Zeigler D.R., Feitelson J., Schnepf E., van Rie J., Lereclus D., Baum J., Dean H.D. 2010. Bacillus thuringiensis toxin nomenclature. Available on: http://www.biols. susx.ac.uk/Home/Neil_Crickmore/Bt/index.html[Accessed: October 23, 2015].

El Khoury M., Azzouz H., Chavanieu A., Aíbdelmalak N., Chopineau J., Awad M.K. 2014. Isolation and characterization of a new Bacillus thuringiensis strain Lip harboring a new crylAa gene highly toxic to Ephestia kuehniella (Lepidoptera: Pyralidae) larvae. Archives of Microbiology 196 (6): 435-444. DOI: https://doi.org/10.1007/s00203-014-0981-3

Facknath S. 1999. Control of Plutella xylostella and Crocidolomia binotalis through the combined effects of Bacillus thuringiensis and botanical pesticides. Food and Agricultural Research Council 99: 87-92.

Federici B.A., Park H.W., Sakano Y. 2006. Insecticidal protein crystals of Bacillus thuringiensis. p. 195-236. In: "Inclusions in Prokaryotes" (J.M. Shively, ed.). Springer-Verlag Berlin, Heidelberg. DOI: https://doi.org/10.1007/7171_008

Hernandez-Fernandez J., Ramírez L.N., Fuentes L.S., Jiménez J. 2010. Molecular and biological characterization of native 
Bacillus thuringiensis strains for controlling tomato leafminer (Tuta absoluta Meyrick) (Lepidoptera: Gelechiidae) in Colombia. World Journal of Microbiology and Biotechnology 27 (3): 579-590. DOI: https://doi.org/10.1007/s11274010-0493-5

Hernstand C., Soares G.G., Wilcox E.R., Edwards D.I. 1986. A new strain of Bacillus thuringiensis with activity against coleopteran insects. Biotechnology 4 (4): 305-308. DOI: https://doi.org/10.1038/nbt0486-305

Hongyu Z., Ziniu Y., Wangxi D. 2000a. Composition and ecological distribution of Cry proteins and their genotypes of Bacillus thuringiensis isolates from warehouses in China. Journal of Invertebrate Pathology 76 (3): 191-197. DOI: https://doi.org/10.1006/jipa.2000.4970

Hongyu Z., Ziniu Y., Wangxi D. 2000b. Isolation, distribution and toxicity of Bacillus thuringiensis from warehouses in China. Crop Protection 19 (7): 449-454. DOI: https://doi. org/10.1016/s0261-2194(00)00036-3

Keyhanian A.A., Taghizadeh M., Taghadosi M.V., Khajehzadeh Y. 2005. A faunistic study on insect pests and its natural enemies in canola fields at different regions of Iran. Pajouhesh and Sazandegi 68: 2-8.

Laemmli U.K. 1970. Cleavage of structural proteins during the assembly of the head of bacteriophage T4. Nature 227 (5259): 680-185. DOI: https://doi.org/10.1038/227680a0

Li Z., Zalucki M.P., Yonow T., Kriticos D.J., Bao H., Chen H., Hu Z., Feng X., Furlong M.J. 2016. Population dynamics and management of diamondback moth (Plutella xylostella) in China: the relative contributions of climate, natural enemies and cropping patterns. Bulletin of Entomological Research 106 (02): 197-214. DOI: https://doi.org/10.1017/ s0007485315001017

Lowry O.H., Rosebrough N.J., Farr A.L., Randall R.J. 1951. Protein measurement with the Folin phenol reagent. The Journal of Biological Chemistry 193 (1): 265-75.

Maeda M., Mizuki E., Nakamura Y., Hatano T., Ohba M. 2000. Recovery of Bacillus thuringiensis from Marine Sediments of Japan. Current Microbiology 40 (6): 413-422. DOI: https://doi.org/10.1007/s002840010080

Ohba M., Aizawai K. 1986a. Distribution of Bacillus thuringiensis in soils of Japan. Journal of Invertebrate Pathology 47 (3): 277-282. DOI: https://doi.org/10.1016/0022-2011(86) $90097-2$

Ohba M., Aizawa K. 1986b. Insect toxicity of Bacillus thuringiensis isolates from soils in Japan. Journal of Invertebrate Pathology 47 (1): 12-20. DOI: https://doi.org/10.1016/00222011(86)90158-8

Oppert B., Tracy E.R., Babcock J. 2010. Effects of Cry1F and Cry34Ab1/35Ab1 on storage pests. Journal of Stored
Products Research 46 (3): 143-148. DOI: https://doi.org/ 10.1016/j.jspr.2010.01.003

Quezada-Moraga E., Garcia-Tovar P., Valverde-Garcia P., Santiago-Alvarez C. 2004. Isolation, geographical diversity and insecticidal activity of Bacillus thuringiensis from soils in Spain. Microbiological Reviews 159 (1): 9-71. DOI: https://doi.org/10.1016/j.micres. 2004.01.011

Renganathan K., Rathinam X., Danial M., Subramaniam S. 2011. Quick isolation and characterization of novel $\mathrm{Ba}$ cillus thuringiensis strains from mosquito breeding sites in Malaysia. Emirates Journal of Food and Agriculture 23 (1): 17-26. DOI: https://doi.org/10.9755/ejfa.v23i1.5309

Sarfraz M., Dosdall L.M., Keddie B.A. 2006. Diamondback moth-host plant interactions: implications for pest management. Crop Protection 25 (7): 625-639. DOI: https://doi. org/10.1016/j.cropro.2005.09.011

Schenepf E., Crickmore N., Rie J.V., Dean D.H. 1998. Bacillus thuringiensis and its pesticidal crystal proteins. American Society for Microbiology 62: 775-806.

Swamy H.M., Asokan R., Mahmood R., Hagesha S.N. 2013. Molecular characterization and genetic diversity of insecticidal crystal protein genes in native Bacillus thuringiensis isolates. Current Microbiology 66 (4): 323-330. DOI: https://doi. org/10.1007/s00284-012-0273-6

Talekar N.S., Shelton A.M. 1993. Biology, ecology and management of the diamondback moth. Annual Review of Entomology 38 (1): 275-301. DOI: https://doi.org/10.1146/annurev.ento.38.1.275

Travers R.S., Martin P.A.W., Reichelderfer C.F. 1987. Selective process for efficient of soil Bacillus spp. Applied and Environmental Microbiology 53: 1263-1266.

Uribe D. 2004 Ecología y distribuciónde Bacillus thuringiensis. p. 101-122. In: "Bacillus thuringiensis en el control biológico. 1st ed. Editiorial Buena Semilla, Bogatá, Colombia.

van Frankenhuyzen K. 2009. Insecticidal activity of Bacillus thuringiensis crystal proteins. Journal of Invertebrate Pathology 101 (1): 1-16. DOI: https://doi.org/10.1016/j. jip.2009.02.009

Vidal-Quist J.C., Castanera P., Cabrera J. 2009. Diversity of Bacillus thuringiensis strains isolated from Citrus Orchards in Spain and evaluation of their insecticidal activity against Ceratitis capitata. Journal of Microbiology and Biotechnology 19: 749-75.

Zhong C.H., Ellar D.J., Bishop A., Johnson C., Lin S.S., Hart E.R. 2000. Characterization of a Bacillus thuringiensis $\delta$-endotoxin which is toxic to insects in three orders. Journal of Invertebrate Pathology 76 (2): 131-139. DOI: https:// doi.org/10.1006/jipa.2000.4962 